\title{
Species-Being and the Badness of Extinction and Death
}

\section{Christine M. Korsgaard}

\begin{abstract}
This paper offers an account of the property Feuerbach and Marx called "species-being," the human being's distinctive tendency to identify herself as a member of her species, and to think of the species as a "we." It links the notion to Kant's theory of rights, arguing that every claim of right commits the maker of that claim to something like world government, and therefore to the conception of humanity as a collective agent. It also links species-being to the concept of practical identity, arguing that the conceptions under which we find our lives and actions valuable are ones according to which we make a positive contribution to the life of the species. It then argues that the resulting conception of humanity, together with certain considerations about the nature of the good, provides grounds for challenging the familiar claim that death is generally worse for human beings than for animals. On the other hand, because of species-being, the extinction of our species is a much worse prospect for human beings than for the other animals.
\end{abstract}

Keywords Animals $\cdot$ Collective agency $\cdot$ Death $\cdot$ Extinction $\cdot$ Humanity $\cdot$ Speciesbeing 
... what I say will be based on the assumption that death is nothing, and final. I believe there is little to be said for it. It is a great curse, and if we truly face it nothing can make it palatable except the knowledge that by dying we can prevent an even greater evil. (Thomas Nagel, The View from Nowhere) ${ }^{1}$

\section{Introduction}

Karl Marx, following the German philosopher Ludwig Feuerbach, argued that human beings have a distinctive property that he called "species-being" (Marx 1988). In this paper I will explain what I think this property is, and trace its relationship to two other philosophical ideas - the idea that humanity is in a sense a single collective agent, which is implicit in Kant's theory of right, and my own idea that human beings have a specifically normative form of identity, practical identity, which involves thinking of ourselves in normative or evaluative terms. ${ }^{2}$ Putting these three ideas together enables us to form a picture of one way in which human beings are different from the other animals: namely, we need to believe that we and our lives have value, and we find that value in contributing to the ongoing collective life of our species. I will then consider the ramifications of that difference for two questions that arise in animal ethics, namely, whether death is worse for human beings than it is for the other animals, and whether the extinction of a species is a bad thing for its members.

\section{Species-Being}

The idea of species-being as a distinctive human property involves the thought that human beings are the only animals who actually think of ourselves, or identify ourselves, as members of a species. Any animal recognizes her own kind, of course, and sees members of her own kind as potential mates, as rivals for mates or for territory, and in some cases as possible social partners of other kinds: a stray dog may join a pack or colony of other stray dogs, say. But in the human case it is more than that. We human beings identify with our species as a whole. We often describe human beings as "we," as I just did in this sentence. We also address human beings, sometimes taking as our potential audience all human beings, as simply "we." Philosophical writing standardly does this, although admittedly in earlier writings there are jarring moments when you suddenly realize that the author did not really suppose that women, or members of the lower classes, or members of other races formed even a potential part of his audience. ${ }^{3}$ We think of our lives in

\footnotetext{
1 Nagel (1986, p. 224).

2 See Korsgaard (1996a, lecture 3, especially 3.3.1, pp. 100-102); and Korsgaard (2009, 1.4, pp. 18-26).

3 To give just one example: Sidgwick (1981), in Book IV of The Methods of Ethics, suddenly makes it clear that his book is addressed not to humanity generally, but to intellectuals who, if convinced by his arguments, might try to bring about utilitarian reforms in common sense ethics. Sidgwick adjures such
} 
a narrative way, as stories, and when we do that, we necessarily place them in larger contexts, in which they interact with the stories of other human beings - the histories of traditions, movements, or nations. The ultimate context in which we place our stories is often the story of humanity itself. We think of humanity as having a shared history, and of our own personal stories as involving the role we play in that shared history. What exactly the human story is varies from generation to generation and place to place, of course. In the middle ages in Christian Europe, the story was the one extending from the story in the Bible-God gives the commandments to Moses, Jesus comes to save us, and eventually history comes to an end and the saved and the damned are assigned their rightful places in the cosmos. For Marx, it was a story about the inevitable triumph of the working classes and the eventual dissolution of the state. In most of the West, since the Enlightenment, it has been a story about political and technological progress, with ever-growing mastery over nature through medical and technological improvements, and ever-growing equality among human beings. Peter Singer inserted himself firmly into that narrative when he began Animal Liberation with the announcement that all animals are equal, and a comparison of his own book to Mary Wollstonecraft's Vindication of the Rights of Women (Singer 2009, p. 1). The part of that story that concerns our technological mastery over nature is now under threat from climate change. But species-being is strong enough that even many of us who will not be much affected ourselves are scrambling to find clean energy sources or pay for our carbon footprints, or in some other way to make sure that we feature as the good guys rather than as the villains in the resulting story.

The idea is that none of this is true of the members of other species. Admittedly, some people would say there is no interesting contrast to be drawn here: a nonhuman animal cannot think of herself as part of a "we" because, not being selfconscious, she cannot even think of herself as an "I." ${ }^{4}$ The interesting difference is more fundamental and so comes, as it were, sooner than species-being. For myself, I don't think this is exactly right. A non-human animal may not think of herself as an "I," but self-consciousness comes in many different forms, some of which animals must certainly have. Here are a few: (1) Pain and pleasure, which serve to inform an animal not merely of facts about the world but of facts about her own relationship to things outside of and about her own condition, are forms of self-consciousness. An animal who feels pleasure or pain is aware of herself in the sense that she can feel her own existence. (2) Action requires that an agent orient herself with respect to her environment, and this is not possible merely on the basis of information about the environment itself: the agent has to know how her own body is related to things

intellectuals to be cautious about the effects of those reforms on the minds of ordinary people, because it may be better that the latter believe that common sense ethical prescriptions are universal and absolute.

4 Immanuel Kant wrote: "The fact that man can have the idea 'I' raises him infinitely above all the other beings living on earth. By this he is a person; and by virtue of the unity of his consciousness, through all the changes he may undergo, he is one and the same person - that is, a being altogether different in rank and dignity from things, such as irrational animals, which we can dispose of as we please." (Kant 1974, $8: 127$ _-references to Kant will be given in the usual way by the page numbers of the relevant volume of Kants gesammelte Schriften, which appear in the margins of most translations. For further discussion of this passage see Korsgaard (2018a, 2.3.2-2.4, pp. 30-35). 
in the environment, both spatially and causally. More generally, many animals who act seem to have some idea what they are doing. This shows up in the fact that, like human agents, they adjust their movements in the face of obstacles and other contingencies so that they can succeed in carrying them out after all. But knowing what you are doing is a kind of self-consciousness. (3) Social animals must know their own place in a dominance hierarchy. Again, this shows in the way they adjust their behavior in accordance with their relations with those around them. All of these kinds of relational knowledge imply some sense of the relation between you and the rest of the world, and therefore of the distinction between you and the rest of the world, and that is what it is to be self-conscious. ${ }^{5} \mathrm{I}$ also believe that many animals have senses of membership, in a social group, or a family, that are functionally equivalent to thinking of themselves as part of a "we." But they do not think of their whole species as a "we."

Others might say that there is no interesting contrast because, lacking language, the members of other species cannot narrate their histories to themselves and each other. But it is more than that. The other species do not have much in the way of histories. Sometimes the members of a species colonize new territory, or change their eating habits to accommodate changed conditions. As scientists have recently learned, specific communities of animals do have bits of culture handed down through the generations. They have a kind of shared lore concerning what to eat; how to find, secure, or prepare it; and which plants have medicinal value. But for the most part the history of a species is only a history of what happens to it, not a history of what they collectively did. And even the history of what happened to them as a species has no trajectory except towards survival or extinction, and in the end, it is always extinction. There would not be much of a story to tell even if they did know how to tell it. So even if species-being can be explained in terms of more fundamental differences between human beings and the other animals, it does seem as if the idea of species-being marks an interesting difference as well.

\section{Humanity as a Collective Agent and Kant's Theory of Right}

There are two other philosophical views that I find it natural to combine with the idea of species-being. The first, which I will discuss in this section, is the view that humanity is, potentially at least, a kind of single collective agent. When we ask whether "we" will ever achieve a permanent peace, or make it to distant solar systems, or discover a cure for cancer, we are thinking of ourselves in that way. Perhaps that is already implicit in Marx's idea. There are two obvious things that make it possible for us to think of ourselves as a collective agent. One is that we have language, and find ways to translate our various languages into each other, so

\footnotetext{
5 Members of an audience who heard this paper suggested that animal self-consciousness could only be a form of what Kant calls "inner sense," not the kind of self-consciousness involved in apperception that Kant was talking about in the passage I quoted in footnote 5. This may be true about the kind of selfconsciousness involved in pleasure and pain, but I have doubts about whether the idea of inner sense can capture the kind of self-consciousness involved in an animal's knowing what he is doing. Obviously this is too complex a question to take up here.
} 
that we are capable of communicating with each other and forming shared plans at a potentially universal level. The other is that we are by nature a highly cooperative and social species, ready to work together to achieve shared ends.

But I have something more specific in mind. People often point out that the logical trajectory of the social contract theory of the political state is towards world government or at least some sort of world federation. The same pressures that induce a group of human beings to join together in a political state should induce the various political states to join together in some larger federation, with at least some shared laws and policies, like the (now perhaps endangered) European Union. ${ }^{6}$ A political state meets what is perhaps the most demanding criterion for collective agency. First, it has formal procedures for making decisions that constitute those decisions as ones that can be attributed to the state itself. Second, it has institutions for carrying out those decisions that constitute the resulting actions as actions of the state itself. When the legislature passes a law, the state makes a collective decision, and when the officials of the state enforce the law, the people of the state act together to carry out that decision, as a single collective agent. So social contract theory points to a quite specific and formal way in which humanity can become a collective agent. Groups of people become a collective agent when they are citizens of a state, and humanity as a whole could become a collective agent if a world state or federation were formed.

These ideas take on a special resonance in Kant's theory of right. Perhaps the most important difference between Kant's version of the social contract story and others is that Kant believed that entry into the political state is a duty (Kant 1996, 6:307). For others, at least for Locke, it was only a remedy for the inconveniences of a lawless condition in which everyone acts on his or her own judgment (Locke 1980, p. 42). To understand the reasons for Kant's view, it is important to consider a special feature of the concept of a right. ${ }^{7}$

Considered as normative entities, rights have an unusual feature: there is a sense in which they do not exist at all until they are instituted legally. For this reason, someone being abused or disrespected in certain ways can voice the exact same complaint by protesting that she has no rights or by protesting that she does have rights. Because of this feature, there is an interesting problem about what is going on when someone makes the case for a legal right.

Suppose I argue that someone "should have a right." That formulation has the disadvantage of making it sound as if all I am saying is that there is something to be said in favor of her having the right, some reasons that would support the policy of giving her the right. But that may not seem like the correct way to argue for a right, since a right ordinarily functions as a trump and a trump requires something stronger than some considerations in its favor. If I have a right to something, call it X, then you have no right to deprive me of $\mathrm{X}$. My right is supposed to be a decisive consideration

\footnotetext{
6 Kant, whose views I am about to discuss, notoriously and somewhat puzzlingly stops short of endorsing world government, although his views seem to call for it. See Kant (1996, 6:350-351), (1991a, 8:24-26), (1991c, 8:307-313), (1991b, 8:354-357).

7 The argument that follows is lifted from my forthcoming paper, "The Claims of Animals and the Needs of Strangers: Two Cases of Imperfect Right.” (Korsgaard n.d.).
} 
against your depriving me of $\mathrm{X}$, however good your reasons for depriving me of $\mathrm{X}$ would be if I did not have the right. So to say that $\mathrm{I}$ have a right to $\mathrm{X}$ is not just to say that there is a very strong reason for me to have $\mathrm{X}$ : it is to say something about the relations in which I stand to those against whom I claim the right. However good others' reasons are for depriving me of $\mathrm{X}$, they will be wronging me if they do so. That includes my relations to society collectively speaking. But if my right is a trump even against society collectively speaking, how can society collectively speaking be in a position to grant me the right? When someone claims that she has a right, she is claiming precisely that no one is in a position to deny her that to which she has a right. But if no one is in a position to deny her the right, then it seems as if no one is in a position to grant her that to which she has the right either. What she is saying is precisely that this is not the sort of thing that others may withhold or grant, however good their reasons. Consider, for instance, the idea that a nation might give its slaves a right to their freedom. Is another human being's right to her freedom something that it is ours (all of us? the rest of us?) to give? How can society grant someone his freedom, if it was already his own by right?

Some philosophers propose to deal with this problem by invoking the idea of a "moral right" and saying that moral rights are the grounds on which we should establish legal rights. That enables them to split the difference-the moral rights do already exist, although the legal ones do not. Then we can say that what society does when it enacts laws protecting people's rights is not granting them rights they did not already have, but protecting their moral rights by making them legal and so coercively enforceable.

That can sound sensible until we remind ourselves what exactly a right is. A right, at least according to Kant and some others in the natural rights tradition, is-by definition - a claim that may legitimately be coercively enforced. You have a right when you have a claim on others to act in a certain way and it is morally legitimate for you (or for society on your behalf) to defend yourself with the use of force against violations of that claim. Not all moral claims, we believe, may be coercively enforced. I cannot sue you for hurting my feelings or being rude to me or have you thrown into prison for breaking my heart, though you should not do these things. I cannot have you arrested if you fail to open a door for me when my arms are full of packages or to help me change a tire by the side of the road. How do we draw the distinction? Some philosophers would argue that the distinction should be drawn on pragmatic or consequentialist grounds: on whether the costs of coercive enforcement are worth preventing wrongs of this kind. Kant, however, believed that the distinction is based on principle. Since coercion is in general wrong, we may only use it against coercion itself, when we are, as Kant puts it, "hindering a hindrance to freedom" (Kant 1996, 6:231). According to Kant, I am free when I can pursue my own ends and in doing so I am not subject to the wills of other people. I am not made subject to your will when you try to break my heart, for I am perfectly free not to care. I am not made subject to your will when you fail to open a door for me, because that does not stop me from going through the door. But I am made subject to your will when you enslave me or make use of my person or my property without my consent. So my claims against you doing those things are coercively enforceable - that is, they are rights. 
This account of what makes a moral claim one of right makes trouble for the proposed use of the distinction between moral and legal rights. It follows from it that if there are any rights, there is a sense in which they already have the status of law: that is, they may legitimately be coercively enforced. This, after all, is why we think it can sometimes be morally legitimate for people to fight even their own governments (or perhaps I should say, the governments over their own territories) for their freedom: because they have a coercively enforceable right to that freedom even if there is no positive law upholding it. On this view, natural right is underwritten by natural law. So the state cannot be seen as making it possible to coercively enforce a claim that is already there, since the claim was not only already there, but already coercively enforceable too.

Now this may not seem like a big problem. For of course there is still a question about the relation between law in this natural sense and the positive statutes that are actually passed by some political society. So why shouldn't we say that a state that makes a law establishing a right is simply acknowledging a natural right that is already there, by making its own laws match the natural laws?

But there's a problem with this too, which was brought out first by Hobbes, and then, following him, Kant. Their views imply that there is a sense in which rights do not exist even morally until laws upholding them are enacted by political society. After all, to say that a right exists morally is not only to imply that you are entitled to defend your claim with force. It is also to imply that people have a moral obligation to respect your claim. But both Kant and Hobbes argued that no one can be morally obligated to respect my rights until he has some guarantee or assurance that I will respect his rights. For if I force you to respect my rights without giving you a guarantee that I will respect yours, then I am putting you in a position where you are subject to my will and so unfree. Or as Hobbes put it, a person who respects the rights of others when they do not respect his "would but make himself a prey to others, and procure his own ruin" (Hobbes 1994, p. 9). ${ }^{8}$ Hobbes and Kant argued that it follows that no one has a duty to respect anyone's rights until some mechanism of enforcing everyone's rights is in place. Since a right involves a duty on the part of others to uphold that right, and others cannot have that duty unless their rights are upheld as well, rights occupy what we might call interpersonal space-my rights and yours can only be realized together.

Kant and Hobbes drew slightly different conclusions from this, however. Putting the point only a little bit facetiously, Hobbes concluded that there is no right or wrong in the state of nature, while Kant concluded that we are never actually quite in the state of nature (cf. Hobbes 1994, p. 78). Our commitment to the enforcement of rights requires that the political state is always already implicitly there.

Putting the point more properly, Kant argued that it is only the political state that can provide the needed guarantees of the enforcement of everyone's rights. So if I say, "I have a right to X," I make a demand on others that I am not in a position to make unless we live together in a political state: claims of right presuppose the existence of the political state. That is, they presuppose our membership in

\footnotetext{
${ }^{8}$ Kant says: "No one is bound to refrain from encroaching on what another possesses if the other gives him no equal assurance that he will observe the same restraint towards him." (Kant 1996, 6:307).
} 
a collective body with a General Will devoted to upholding the rights of all. Claims of right presuppose this even if we are in the state of nature and the political state exists only in idea. So when I claim a right in the state of nature I commit myself to supporting the existence of a political state. This means that we have a duty to live in the political state. Our rights in the state of nature, are, as Kant put it, "provisional." They exist in the sense that we have the right to defend them, but not in the sense that anyone else has a duty to respect them. It is only when the state is actually formed that they become, again as Kant put it, "conclusive" (Kant 1996, 6:256-257).

Kant's distinction between provisional and conclusive rights explains the status of natural rights much better than distinction between moral and legal rights does. Provisional rights are in one sense already legal, since the right-holder is morally entitled to coercively enforce them. In another sense, however, they are not yet quite moral, since no one else is obligated to respect them. What society does when it legalizes a right is neither to grant the right holder something that is already his own and not society's to give, nor to legalize a merely moral right that is already there by making it enforceable. What society does instead is to realize a right whose existence is essentially incomplete or imperfect-provisional-in the state of nature.

All of this has an important implication. It is that when you claim a right, you commit yourself to the existence of the political state, even if you are in the state of nature and the political state doesn't exist yet. For when you claim a right, you are acting in the name of the political state.

Kant thought of the primary kind of right as a right to a piece of land, and he thought of the claim that you make when you claim your right as one that you make in the first instance against those who hold adjacent territory. So the natural shape of a political state is a bounded territory. But as Kant himself liked to emphasize, the world is round, so all territory is ultimately adjacent (Kant 1996, 6:311). That means that, provisionally at least, when you claim a right, you claim it as against all of the rightful inhabitants of the earth. Kant, of course, took it for granted that this meant all the human inhabitants of the world. That is why, in his version of the social contract theory, the trajectory of the argument is towards world government or at least world federation. ${ }^{9}$ That means that whenever you claim a right, you commit yourself to the existence of some sort of world government or federation, and so to the existence of humanity as a collective agent.

So if Kant is right, it is not merely possible for humanity to become a collective agent, because of our linguistic and cooperative nature. We are all committed to that happening, on pain of our not having any conclusive rights. Species-being is not just a natural tendency. It is a moral commitment. We human beings must at least think of ourselves as a "we" engaged in a collective project of achieving universal justice. Our other narratives must, if they are to be rational and moral, take place within that framework.

\footnotetext{
9 There's an obvious question about whether anything short of world government could really guarantee universal rights that I'm not going to take up here.
} 


\section{Rationality as the Human Difference}

I said there were two views I think of as going with the idea of species-being. One is the Kantian story I have just told about why human beings have to think of ourselves as a collective agent. The other view is my own story about why human beings have what I have called "practical identity," descriptions of ourselves under which we value ourselves and find our lives worth living and our actions worth undertaking. Practical identities, I have argued before, are given by the roles and relationships that give our lives meaning. We can connect that idea to species-being because it is our practical identities that serve as the main characters in the narratives that we embed into the larger human story. ${ }^{10}$

Practical identity is, like species-being, supposed to be a specifically human attribute. In this section I will start to explain why that is by explaining the central difference between human beings and the other animals from which it arises: rationality.

A non-human animal, I believe, lives in a world that is in a deep way her own world, a world that is for that animal. I do not mean that the animal's world is favorable to her interests; often it is not. But the world as perceived by the animal herself is organized around her interests: it consists of the animal's food, her enemies, her potential mates, and, if she is social, of her fellows, her family, flock, tribe or whatever. This is a way of saying that the animal's representations of things come already loaded with the practical significance of various objects for her. She confronts a world of things that are perceived directly, without calculation or conscious interpretation, as things that are to-be-avoided, to-be-chased, to-be-investigated, tobe-eaten, to-be-fled, to-be-cared-for, and so on. If you think of it, you will see that it has to be this way. Perception first evolved in animals who are not highly intelligent, and would have been useless if all it did was flood their minds with neutral information that needs to be processed by intelligence or reason before it can be of any use. So the world comes to an animal already practically interpreted as a world of resources and obstacles, of friends and enemies, of the to-be-avoided and the tobe-sought. The natural way of perceiving the world, as I like to put it, is teleologically: everything has its place in a purposive order determined by the instincts of the perceiving animal herself.

As I have just suggested, we can use the traditional word "instinctive" for this way of perceiving and responding to the world, and it is convenient to do so. "Instinctive" naturally contrasts with "rational." Following a tradition going back to Aristotle, that's what I am claiming is different about human beings- that we are rational. But before I can use the words "rational" and "instinctive," I need explain something about the way I am using them.

Sometimes people use the term "instinctive" for reactions and movements that are wholly automatic and simply caused, not intentional, like ducking or salivating. I am not talking primarily about reactions of that kind. But it will make it easier to explain how I am using it when I also explain something about how I am using

10 The rest of this section and much of the next also appears in Korsgaard (2018a, Chapter 4): "What's Different about Being Human?". 
"rational." People sometimes contrast an instinctive response to an intelligent or learned response, and I am not doing that either. As I am using the terms, being instinctive is compatible with being intelligent, which is not the same thing as being rational.

An intelligent animal is characterized by his ability to learn from his experiences, and to solve problems by taking thought. Through learning, he is able to extend his repertoire of practically significant representations beyond those with which his instincts originally supplied him. He might learn to see the porcupine as something that is to-be-avoided or a human companion as a member of his flock, for example. He might learn to solve a problem by making a tool. Intelligence so understood is not something contrary to instinct, but rather something that increases its range and ramifies the view of the world that it presents to the creature who has it.

Intelligence, on this showing, is not the same as rationality. Rationality, as I use the term, is a normative power grounded in a certain form of self-consciousness. A rational animal is (at least sometimes) aware of the grounds of her beliefs and actions, or rather of what would be their grounds if she were not so aware. By the "grounds" I mean the things that would directly cause her to believe what she believes or to do what she does if she were not in a position to reflect on them. This consciousness puts her in a position to evaluate those grounds and decide whether or not they count as good reasons to act and believe in the ways that they tempt her to act and believe.

When a non-rational animal thinks about what to do (if she thinks about what to do) she thinks about things in the world as she perceives them, not about her own attitudes towards those things. The attitudes that motivate her actions may be invisible to her, because they are part of the lens through which she sees the world, rather than being part of the world that she sees. We sometimes talk as if our own attitudes were invisible to us in exactly this way. If you say that a spider is "creepy", for instance, you speak as if your attitude towards the spider were a property of the spider itself. The particular distaste you have for the spider, the fact that it gives you "the creeps," is a lens through which you see it, causing you to think of the "creepiness" as a property of the spider. If our fear of spiders is instinctive, it is no accident that this example illustrates what I am trying to convey: this is what the kind of perception I am calling "teleological" is like. The perceived creepiness of the spider almost commands you to avoid coming into contact with it. That is why even when you know a spider is harmless, it can be difficult to hold still as it crawls across your arm.

In the same way, we might suppose that when an antelope flees from a lion, she is afraid. But she need not think about the fact that she's afraid, or about the fact that her fear is what is making her run. Perhaps she just sees the lion as danger, as a thing that is to-be-fled. But we human beings are, or can be, aware of the attitudes that motivate our actions and of the facts that motivate our attitudes. We may know, in these kinds of circumstances, that we are afraid, that fear is what is making us want to run, that the possibility of being mauled by the lion is what is making us afraid. That opens up the space in which we can ask a whole new range of questions, normative questions: not only about whether a lion is a good thing to run away from, but also about whether a lion is a good thing to fear, or even about whether fear, 
in these circumstances, is presenting us with a good reason to run. ${ }^{11}$ Perhaps, after all, we are in circumstances that make it worth taking the risk of being mauled by the lion, such as trying to save the life of a child. If we are, as we take ourselves to be, rational beings, then what we actually do will be influenced by the way we answer those questions: we will, for instance, stand our ground if we decide either that we have reason not to be afraid or that we have reason not to run even if fear is in order. Of course reason does not always triumph over instinct in this way, but it can.

So the difference between rationality and intelligence is this: Intelligence looks outward at the world, and asks and answers questions about the connections and relations we find there: most obviously about causal relations, but also spatial and temporal and social relations. But rationality looks inward, at the workings of our own minds, and asks and answers normative or evaluative questions about the connections and relations that we find there. In particular, practical rationality raises questions about whether the attitudes and the facts that motivate our actions give us good reasons to act. Rationality, in this sense, is normative self-government, the capacity to be governed by thoughts about what you ought to do or to believe.

\section{From Rationality to Practical Identity}

How do we get from practical rationality, conceived as the power to ask and answer normative questions about our actions, to practical identity? We can trace the connection in steps.

First, when we become aware that we can evaluate the motives of our actions, and act differently as a result of that evaluation, we become aware, in a way that the other animals are not, that our actions are our own, because what we do is up to us. Or rather, to put the point more properly, it becomes true in a way that it is not true for the other animals that our actions are up to us, and therefore are in a special way our own. What I have in mind here is most obvious when you decide that the motive on which you are tempted to act is not a good reason doing for what you are tempted to do, and therefore decide to refrain from doing it, or to do the opposite thing. If you can override your own instinctive desires when you think that acting on them would be wrong, then you are in one sense responsible for what you do. If we can refrain from performing a certain action or pursuing a certain end even if we want to very badly, then it follows that in a certain sense that when even we do decide to do the tempting action, we are responsible for that too. We could have chosen otherwise.

This in turn makes another difference. When we come to see our actions as up to us in this special way, we come to see them as expressions of ourselves-that is, of our selves. For because we are aware of our own attitudes and motives, or at least of some of them, our sense of our selves includes those motives and attitudes, and

\footnotetext{
11 Philosophers will differ about whether the reason is provided by facts like the fact that the lion might maul you or by mental attitudes such as fear or the desire not to be mauled. I am not taking a stand on that here, although it is difficult to write a sentence without choosing one of these options.
} 
we are aware of this aspect of our selves as the sources of our actions. That means that when we turn an evaluative eye on to our own motives and actions, while at the same time coming to see those actions as up to us, we are effectively turning an evaluative eye onto ourselves. Regarding ourselves as the sources and authors of our actions, and our actions themselves as good or bad, is in effect regarding ourselves as good or bad. When you endorse a certain motive, you are also endorsing a certain aspect of yourself. When we come to take responsibility for our own actions, we see ourselves as good or bad. We've come to have names for various common ways of being good or bad: cowardly, selfish, unjust, or just plain evil; brave, generous, impartial, or just plain good.

When I read or hear discussions about whether there are any important differences between human beings and the other animals, I am always surprised that the one I just mentioned so seldom comes up. I don't mean rationality, but rather the tendency to normative or evaluative self-conception to which it gives rise. For if this is indeed a difference between human life and the lives of the other animal, it is an enormous difference. So far I have talked about morality, but normative or evaluative selfconception does not find its expression in moral self-evaluation alone. It shows up all over the place in human life: in a teenager's desire to be cool or a ruffian's desire not to seem weak or urbanite's desire to be in fashion. We are eager that others should think well of us, and it is not (usually) because we calculate the possible benefits of that-it is because we are eager to think well of ourselves. Thinking well of yourself and thinking that others think well of you are the source of some of a human being's most exquisite pleasures. Feeling unappreciated by others is the source of enormous bitterness for many people. People can be driven to despair or suicide by the thought that they are worthless or useless or unlovely. We want to be good husbands and wives and parents and teachers and leaders and friends. We are always holding ourselves to evaluative standards. None of this, I believe, is true of the lives of the other animals. I feel tempted to say that unlike us the other animals accept themselves as they are, but of course that is not the right way to put it: they do not evaluate themselves at all, so the question of accepting themselves does not come up. A life led in the light — or the shadow — of a normative conception of the self is a very different kind of life from the one that the other animals lead.

\section{Practical Identity and Species-Being}

Normative identity gives human beings a problem to solve. We need to value ourselves, to think well of ourselves, to feel that we-that our selves-are good things. If I am right, this is not a problem that the other animals face. What I have called practical identity - a description under which you value yourself and find your life worth living and your actions worth undertaking - is the positive solution to that problem. Realists about value, believers in something like Moore's intrinsic values, think we solve the problem by aligning ourselves in various ways with those. Here as elsewhere, Kantians replace the metaphysically objective with the intersubjective: what counts as good in the Kantian system is what can be chosen in such a way that everyone can endorse it. And what counts as being a good person is being good in 
the eyes of everyone, being someone whose actions everyone can rationally endorse. This limits us to pursuing ends whose pursuit others have no reason to object to, but it also gives a special place to the pursuit of ends that all of us share. This in turn means that species-being has a special place in the solution of the problem of normative identity. We can see ourselves as valuable, and our lives as having a certain kind of meaning, when we can see ourselves as making a positive contribution to the ongoing activities, the ongoing life, of the collective agent that is humanity.

\section{The Implications for Human and Animal Death}

It is almost universally accepted by people who do animal ethics that the death of a human being is more tragic, a greater loss, for that human being than the death of another animal is for that other animal. ${ }^{12}$ There are four kinds of reasons for this. The first reason springs from the view that because human beings have higher capacities than animals do, human life is flat-out better than animal life, so that we have more to lose by dying than the other animals do. I will call this the higher capacities argument. The second, closely related, argument is that the other animals lack what Bernard Williams calls "categorical desires"- desires for things that make life worth living, or worthy of choice, as opposed to desires that are contingent upon the fact that you are alive. The third reason springs from the view that human life has a narrative structure which is subject to being interrupted in costly ways by death, while non-human animal life does not. I will call this the narrative unity argument. The fourth reason springs from a view about "personal" identity (as we call it, though it applies to the other animals as well). It is alleged that for various reasons, among them the lack of memory of particular experiences, animals are not as psychologically connected over time as human beings are. The idea is that the other animals are not really ongoing psychological entities, or anyway are not to the extent that we are. They are not united with their past and future selves by memories and plans; because they are supposedly un-self-conscious, they have no desires concerning themselves, such as the desire to achieve something in the future, or simply to be alive at some future date. It follows that although comfortableness of their existence at any given moment matters, its duration does not, or not as much as ours does. In its most extreme form, advocated by Peter Singer earlier in his career but modified later, this view is taken to imply that there is no important difference between letting a happy animal go on living, or killing her and replacing her with another happy animal. ${ }^{13}$ One is as good as the other. In its less extreme forms, this view is closely related to the narrative unity argument, because animal's lack

\footnotetext{
12 Although I have not seen it discussed very often, I wonder whether even those who endorse this view might make an exception when the comparison is between a very old human being who has had a good life with no unresolved issues and a very young animal, or one who has undergone uncompensated suffering but might still find happiness ahead.

13 The more extreme view is found in Singer (1979). The view has been modified in the successive editions of Practical Ethics. See the discussion in Singer (2011, 3rd edition, chapter 5).
} 
of psychological unity and her lack of narrative unity go together. I will therefore discuss psychological connectedness and narrative unity together.

\subsection{The Higher Capacities Argument}

Many philosophers, in the tradition of John Stuart Mill, believe that human beings have higher capacities that make our lives just plain better, in the sense of more desirable for us, than the lives of other animals are for them. Human beings enjoy what Mill called the "higher pleasures" of art, music, science, and philosophy, and we have more complex and richer personal relationships. Mill famously argued that because of this, "Few human creatures would consent to be changed into any of the lower animals for a promise of the fullest allowance of a beast's pleasures," and that "It is better to be a human being dissatisfied than a pig satisfied" (Mill 1979, pp. 9-10). Peter Singer agrees. Here he is, in Animal Liberation:

...a rejection of speciesism does not imply that all lives are of equal worth. While self-awareness, the capacity to think ahead and have hopes and aspirations for the future, the capacity for meaningful relations with others and so on are not relevant to the question of inflicting pain ...these capacities are relevant to the question of taking life. It is not arbitrary to hold that the life of a self-aware being, capable of abstract thought, of planning for the future, of complex acts of communication, and so on, is more valuable than the life of a being without these capacities (Singer 2009, p. 20).

Others also extend this kind of thinking to the other animals. Here, for instance, is Jeff McMahan:

Because animals vary considerably in their capacities for well-being, some may be harmed to a greater extent by death than others. For example, because a dog's life is normally richer (in pleasure, social relations, and so on) than a frog's, dogs generally suffer a greater harm in dying (McMahan 2002, p. 192).

You might think that the picture of what is distinctive about human life that I have painted in this paper supports this kind of argument. Human beings, you may have taken me to suggest, live lives fraught with meaning and value, and set a value on ourselves, while animals simply have a pleasant time or not. Our lives are therefore more valuable than theirs, and we have more to lose by death.

But I do not think this is right. The trouble with the higher capacities argument is that it makes a contestable assumption about the relation of a creature's capacities to the possible goodness of her life for her. It assumes that certain activities are good independently of a creature's capacities, and what the creature's capacities determine is which of those goods the creature has access to. Since animals lack our higher capacities, they have no access to the higher pleasures, so their lives are less good for them than ours are for us. I think it makes much better sense to assume that what is good for an animal is relative to her capacities. On this view, opera is not a higher pleasure on which horses miss out because they lack the capacity to enjoy it, any more than eating hay is a pleasure on which you miss out because you lack the capacity to enjoy it. Animals do not lead lives fraught with meaning and value, 
but that is because such things have nothing to do with them. They do not conceive themselves normatively, and do not need practical identities. But their lives are not less good for them because of that.

On the other hand, the fact that we find value in making a contribution to the ongoing life of our species means that for us, there can be such a thing as a reason in favor of dying, or anyway a compensation for it. We can find value in dying to stand up against injustice or to make the world a better place for people later on. We can find that we have a stake in making some contribution to the life of humanity that is greater than our stake in our biological lives, like the author who runs into the fire to save the only copy of his great novel. Our participation in a larger life is, if not a form of immortality, still, a larger life. For the other animals the only thing remotely like this is the survival of offspring. Mostly, for them, death is the end of everything that is or could possibly be good for them. It is more final than it is for us. So in this sense, death can be worse for the other animals.

\subsection{The Categorical Desires Argument}

In "The Makropulos Case: Reflections on the Tedium of Immortality," Bernard Williams distinguishes between what he calls "categorical desires," desires for things that make us want to go on living, and desires that are contingent on the fact that we expect to go on living. He explains it this way:

It is admittedly true that many of the things I want, I want only on the assumption that I am going to be alive; and some people, for instance some of the old, desperately want certain things when nevertheless they would much rather that they and their wants were dead. It might be suggested that not just these special cases, but really all wants, were conditional on being alive... But surely the claim that all desires are in this sense conditional must be wrong. For consider the idea of a rational forward-looking calculation of suicide... In such a calculation, a man might consider what lay before him, and decide whether he did or did not want to undergo it. If he does decide to undergo it, then some desire propels him on into the future, and that desire at least is not one that operates conditionally on his being alive, since it itself resolves the question of whether he is going to be alive. He has an unconditional, or (as I shall say) a categorical desire (Williams 1973, p. 85-86).

Right now I believe that if I am alive twenty years from now, I shall want to have a safe and pleasant place to live and enough food and water, but (the argument suggests) I do not want to live for twenty years in order to have a nice dinner in a safe and pleasant place twenty years from now. Those desires are contingent on my being alive. But I certainly might want to live for another twenty years if I think it will take me that long to solve some philosophical problem I have been working on all my life, or to see some young person I care about make it safely to maturity. 
Those kinds of desires can be categorical. ${ }^{14}$ Now consider the following passage from Jeff McMahan:

There is, of course, a sense in which a squirrel's efforts in gathering nuts for the winter are rendered futile if it is run over by a car. But the squirrel's action was merely instinctive, not deliberate; there was no goal that the squirrel was consciously seeking to achieve. And even if the squirrel had been consciously pursuing a goal, that goal would merely have been survival itself. It would not have been a goal that gave the squirrel a reason for surviving or for wanting to survive (McMahan 2002, p. 198). ${ }^{15}$

McMahan seems to be suggesting that the squirrel's desire, if we can call it that, to have enough nuts to survive on next winter must be understood as what Williams would call a contingent desire; and the larger context of the passage, which we will be discussing in the next section, suggests he is implying that any of the squirrel's desires must be contingent in this way. The overall suggestion would then be that animals do not have any reason to want to exist, although of course there are things that they have a reason to want given that they exist. So their deaths are less regrettable.

Let me make a couple of points about this argument before I say what I think the problem with it is. First of all, I am leaving aside the complex question of whether her offspring give an animal a reason to want to survive, if the animal is among those who care for their offspring. Second, I note that there is a question how closely related this argument is to the higher pleasures argument. If the kinds of activities associated with the higher pleasures are the kinds of activities that give us a reason to want to survive, then the two arguments will be closely related, but I do not think we should necessarily assume that. So I am treating it as a separate argument.

I think there is a problem with this argument. The argument assumes, as it seems to me philosophical arguments on this subject often do, that life, that conscious existence, is something that is in itself neutral. It is something that is good when there are good things in it, and bad when there are bad things in it. I cannot give an adequate defense of what I am about to say here, but this assumption seems to me to be false. ${ }^{16}$ I think that life itself is a good for the creature who lives it, unless it is in some specific way bad. For a conscious creature, a healthy existence under reasonably good conditions is in itself a good, and even when the conditions are less good, good enough to be worth clinging to. Life is never neutral, and when it is not

\footnotetext{
14 I made a distinction similar to Williams' in Korsgaard (1996b) as part of a defense of Aristotle's preference for the contemplative over the political life. It was a distinction between things for which we would choose life itself and things that we choose, although for their own sakes, only given that we are alive. The distinction is not exactly the same, I think, because we might have reasons to go on living once we are alive that wouldn't count as reasons to choose life itself. Or anyway, the question seems to me to be complicated. Nevertheless, I believe that the points I am about to make against the categorical desires argument also have a destabilizing effect on my own early argument.

15 I am not as sure as McMahan seems to be that the fact that the squirrel's action is instinctive means that it is not deliberate, but this is not the place to pursue that argument. See Korsgaard (2018a, 3.2, pp. 38-44), (2018b, pp. 7-9).

16 I defend it in Korsgaard (2018a, 2.1, pp. 16-22).
} 
bad, it is good enough. So we do not need to have categorical desires in order to have a reason to want to go on living; or, if you prefer to put it this way, the desire for life is itself categorical enough. Williams disagrees:

But the question might be raised, at the impoverished end of things, as to what the minimum categorical desire might be. Could it be just the desire to remain alive? The answer is perhaps "no". In saying that, I do not want to deny the existence, the value, or the basic necessity of a sheer reactive drive to selfpreservation: humanity would certainly wither if the drive to keep alive were not stronger than any perceived reasons for keeping alive. But if the question is asked, and it is going to be answered calculatively, then the bare categorical desire to stay alive will not sustain the calculation... (Williams 1973, p. 86).

But it is one thing to say that you need a categorical desire once the question of suicide has arisen, and another thing to say that you need it to stave the question off. And now it seems worth pointing out that for the other animals, that question does not come up: the other animals do not, so far as we know, commit suicide. I suppose that many philosophers would say that all that keeps the animals going is what Williams calls "a sheer reactive drive to self-preservation." The problem here is similar to the problem with the higher pleasures argument. Our lives would be impoverished without intellectual and cultural pleasures, so we think that the lives of other animals must be improverished too. In the same way, to think that what life is like for the animals must be what life would be like for us if we had no categorical desires to keep us going - to think that their condition is like ours at what Williams, in the passage I just quoted, calls "the impoverished end of things"-is a false projection of our own tastes and values onto them.

\subsection{Psychological Connectedness and the Narrative Unity Argument}

Jeff McMahan has argued that death is worse for a human being than for the other animals because human life has a sort of narrative structure. He says:

...the lives of persons typically have a narrative structure that may demand completion in a certain way. People autonomously establish purposes for their lives, form patterns of structured relations with others, and thereby create expectations and dependencies that require fulfillment. The importance of later events in a typical human life may thus be greatly magnified by their relation to ambitions formed and activities engaged in earlier. The goods of a person's expected future life may assume a special significance within the life as a whole if they would bring longstanding projects to fruition, extend previous achievements, resolve conflicts, harmonize hitherto dissonant ambitions, redeem past mistakes, or in general round out or complete the narrative structures established earlier. [...] In the lives of animals, however, this potential for complex narrative unity is entirely absent. There are no projects that require completion, mistakes that demand rectification, or personal relations that promise to ripen or mature. Rather, as Aldous Huxley once put it, "the dumb 
creation lives a life made up of discreet and mutually irrelevant episodes. Each day is merely more of the same" (McMahan 2002, p. 197).

There are a number of problems with this, of which I will mention two. The first is that, as I pointed out earlier, having a narrative conception of your life involves fitting that narrative into the narrative of some larger group of people-ultimately, perhaps, of all people. So the very fact that our lives have narrative unity leads us back to the argument I made in 8.1 about the possible consolations of species-being. It suggests a way in which death is less bad for us. The other problem is that the reflection that human life has a narrative structure could lead us to the opposite conclusion, that death is in some way good for us, since a narrative structure requires a beginning, a middle, and an end. McMahan says it himself: things that are narratively structured "demand completion." An idea like this is also at work in Williams's argument about the tedium of immortality. Williams's argument is complex, but the gist of it is that if you lived for forever, one of two things would happen. Either you would change so much over time that you would become so psychologically distant from your earlier self that you could just as well be someone else. Or you would not change, and things would come to seem monotonous, boring, and pointless. This may seem unduly pessimistic, but the thought is the same: human life wants trajectory. But if something like this is only true of human life, as McMahan supposes, then it is possible that death is good for us, or anyway necessary to our good, in a way that it is not for the other animals. For we can also turn the other part of McMahan's observation upside down. It might seem, for instance, as if a non-human female could find such joy as she is capable of in raising a litter of cubs every year for all eternity, though most of them are doomed to be forgotten and die.

\section{The Dark Side of Species-Being}

Finally I will mention another implication of all this for animal ethics: the question of the badness of extinction. I am not talking here about the impact of the loss of biodiversity on the ecosystem, but about whether the extinction of a species is a bad thing for the members of the species itself. People often write and talk as if caring about the preservation of a species is a way of caring about the animals in that species. For most animals, I do not think this is exactly right. It is obvious that while a species is going extinct, bad things will be happening to its members: they may be dying prematurely in horrible ways: being killed by an invasive predator against whom they have no natural defense, or wiped out by a germ against which they have no immunity, or starving to death because some other species has taken over their food source. They may be unable to reproduce because their numbers are so depleted that they cannot find mates, like Lonesome George, a Galapagos sea turtle who outlived every other member of his species for at least forty years. But even if we think of the other animals as having some stake in their immediate offspring and the community of conspecifics with whom they live, they have no 
stake in the longer term survival of their species. ${ }^{17}$ They have no stake in anything that goes very much beyond their own lives.

But for us it is just the opposite. If the story about species-being is true, the end of the human species would be, for us, nearly catastrophic: an important source of meaning and value of our individual lives would be eliminated. In a recent book, Sam Scheffler has pointed out how few of our activities would make any sense to us if we thought we were in the last generation or so (cf. Scheffler 2016). Why do research to make discoveries that no one will use? Why create works of art that few will enjoy? Why write novels and philosophy that no one will read? Why build houses destined to be inhabited by termites and spiders? And why have children when we know that their lives will be even more pointless than our own?

Of course, if we care about the other animals, there would still be some consolation, but it would be of a rather unsettling kind. For species-being has its dark side. Our thoroughgoing identification with our own species has come at a cost. Human beings have treated the other animals with an endless, unrelenting, unrepentant cruelty. The strange success of our species has been won by using the other animals not only as mere means to our ends, but in ways that are heedless of the other animals' capacity for suffering and joy. At the present time, the overwhelming majority of non-human mammals and birds on the planet are domestic animals, leading lives of utter misery in factory farms. The few wild animals left are being crowded off the planet by habitat destruction, poaching, and recreational hunting. For all of the other animals except those pet animals who are lucky enough to have found a place in good human homes, the extinction of humanity would be an unmitigated boon. ${ }^{18}$

Open Access This article is distributed under the terms of the Creative Commons Attribution 4.0 International License (http://creativecommons.org/licenses/by/4.0/), which permits unrestricted use, distribution, and reproduction in any medium, provided you give appropriate credit to the original author(s) and the source, provide a link to the Creative Commons license, and indicate if changes were made.

\section{References}

Hobbes, Thomas. 1994. Leviathan. Edited by Edwin Curley. Indianapolis: Hackett Publishing Company. Kant, Immanuel. 1974. Anthropology from a Pragmatic Point of View. Translated by Mary Gregor. The Hague: Martinus Nijhoff.

Kant, Immanuel. 1991a. Idea for a Universal History with a Cosmopolitan Purpose. Translated by H. B. Nisbett in Kant's Political Writings, second edition. Edited by Hans Reiss. Cambridge: Cambridge University Press.

Kant, Immanuel. 1991b. Perpetual Peace: A Philosophical Sketch. Translated by H. B. Nisbett in Kant's Political Writings, second edition. Edited by Hans Reiss. Cambridge: Cambridge University Press.

Kant, Immanuel. 1991c. On the Common Saying: This May Be True in Theory but It Does not Apply in Practice. Translated by H. B. Nisbett in Kant's Political Writings, second edition. Edited by Hans Reiss. Cambridge: Cambridge University Press.

Kant, Immanuel. 1996. Metaphysics of Morals. Translated by Mary Gregor. Cambridge: Cambridge University Press.

Korsgaard, Christine M. 1996a. The Sources of Normativity. Cambridge: Cambridge University Press.

\footnotetext{
17 For an argument that they do have such a stake, see Korsgaard (2018a, 11.6, pp. 204-208).

18 This paper was originally written for a conference in honor of Richard Schacht. I thank the organizers for inviting me to write it, and the audience on that occasion for their feedback.
} 
Korsgaard, Christine M. 1996b. Aristotle and Kant on the Source of Value. In Creating the Kingdom of Ends. Cambridge: Cambridge University Press.

Korsgaard, Christine M. 2009. Self-Constitution: Agency, Identity, and Integrity. Oxford: Oxford University Press.

Korsgaard, Christine M. 2018a. Fellow Creatures: Our Obligations to the Other Animals. Oxford: Oxford University Press.

Korsgaard, Christine M. 2018b. Prospects for a Naturalistic Explanation of the Good. Proceedings of the Aristotelian Society Supplementary Volume XCII.

Korsgaard, Christine M. (forthcoming). The Claims of Animals and the Needs of Strangers: Two Cases of Imperfect Right.

Locke, John. 1980. Second Treatise of Government. Indianapolis: Hackett Publishing Company.

Marx, Karl. 1988. Economic and Philosophic Manuscripts of 1844. Translated by Martin Milligan. New York: Prometheus Books.

McMahan, Jeff. 2002. The Ethics of Killing: Problems at the Margins of Life. Oxford: Oxford University Press.

Mill, John Stuart. 1979. Utilitarianism. Edited by George Sher. Indianapolis: Hackett Publishing Company. Nagel, Thomas. 1986. The View from Nowhere. New York: Oxford University Press.

Scheffler, Samuel. 1981. Death and the Afterlife. New York: Oxford University Press, 2016.

Sidgwick, Henry. 1981. The Methods of Ethics. Indianapolis: Hackett Publishing Company.

Singer, Peter. 1979. Killing Humans and Killing Animals. Inquiry: An Interdisciplinary Journal of Philosophy 22, pp. 145-156.

Singer, Peter. 2009. Animal Liberation. First Published 1975, updated in 1990, 2002, and 2009. New York: Harper Collins.

Singer, Peter. 2011. Practical Ethics, 3rd Edition. Cambridge: Cambridge University Press.

Williams, Bernard. 1973. The Makropulos Case: Reflections on the Tedium of Immortality. In Problems of the Self. Cambridge: Cambridge University Press. 